\title{
Serum complement component depression during acute adenovirus conjunctivitis
}

\author{
A. K. GUPTA AND G. S. SARIN \\ From the Guru Nanak Eye Centre and Maulana Azad Medical College, New Delhi
}

SUMmary Serum C1q, C3, C4, and C5 components of complement levels were measured in 35 healthy subjects and 29 patients with acute conjunctivitis due to adenovirus type 2 , 7 , and 8 infections. Serum C1q and C3 levels were found to be significantly low, and there was no change in serum C4 and C5 levels. A progressive decline in the serum complement level with the severity of disease was observed. The change in the complement levels in serum showed a tendency to reach normal levels with clinical improvement.

The complement system plays a role in defending the host against infection. ${ }^{1}$ It consists of a group of proteins of 19 components that are normally present in a native or inactive state. ${ }^{2}$ The complements may potentiate immunopathological injury as well as decrease replication in viral infection. ${ }^{3}$ Activated complement is an important mediator of tissue inflammation. ${ }^{4}$ The ocular tissue is known to contain components for both classical and alternate pathways of activation of complement. ${ }^{5}$

The serum and tear immunoglobulin profile has been studied in patients with acute adenovirus conjunctivitis. ${ }^{6}$ However, no study has been reported on the serum complement component concentrations in this disease. Here we report observations on the complement levels in serum in patients suffering from acute adenovirus conjunctivitis, in the acute stage and in remission, which occurred in epidemic form during July and August 1981 . The findings regarding adenovirus culture and serological titres have been described elsewhere. ${ }^{7}$

\section{Material and methods}

The study was carried out among 35 healthy subjects and 29 patients with virologically confirmed acute adenovirus conjunctivitis attending the outpatient department of Guru Nanak Eye Centre, New Delhi. The control group comprised healthy subjects who had no evidence of ocular or systemic disease and who attended the Eye Centre during the same period Correspondence to Dr A. K. Gupta, VI/6 Maulana Azad Medical College Campus, Kotla Road, New Delhi, 110 002, India. mainly for the purpose of refraction. In the control group were 28 males and 7 females with a mean age of 32.1 years, and the patients comprised 24 males and 5 females with a mean age of 31.2 years. The diagnosis of acute adenovirus conjunctivitis was established by detailed clinical examination including slit-lamp biomicroscopy, bacterial culture, viral culture, and specific serological studies. The patients were subgrouped as mild, moderate, and severe according to the intensity of chemosis and congestion. Seventeen cases were due to adenovirus type 8,5 to adenovirus type 7 , and 8 to adenovirus type 2 .

The samples of serum were stored at $-20^{\circ} \mathrm{C}$ until assayed. They were analysed for complement components by single radial immunodiffusion. ${ }^{8}$ Monospecific goat antisera against human $\mathrm{C} 3, \mathrm{C} 4$, and $\mathrm{C} 5$ components of complement and their respective standards were obtained from Meloy Laboratories, Virginia, USA. Antihuman C1q complement component serum was obtained from Behring Institute, Frankfurt, West Germany. The levels of $\mathrm{Clq}$ component of complement in the samples of sera were compared with the WHO reference standard serum 67/97 and expressed in units per $\mathrm{dl}$, the WHO reference standard serum being taken as 100 units per dl. In 10 patients the serum samples were collected during the stage of remission when there was no clinical evidence of the disease.

\section{Results}

Serum C3, C4, C5, and C1q components of complement level in patients with acute adenovirus 
Table 1 Serum complement component levels in $\mathrm{mg} / \mathrm{dl}(\mathrm{C3}, \mathrm{C4}, \mathrm{C5})$ and units/dl $(\mathrm{Clq})$ in normal controls and acute adenovirus conjunctivitis

\begin{tabular}{|c|c|c|c|c|c|c|}
\hline \multirow[t]{2}{*}{ Complements } & \multicolumn{3}{|c|}{ Normal control } & \multicolumn{3}{|c|}{ Acute adenovirus conjunctivitis } \\
\hline & Mean & $S D$ & Range & Mean & $S D$ & Range \\
\hline $\mathrm{Clq}$ & $134 \cdot 2$ & $35 \cdot 2$ & $65 \cdot 9-195 \cdot 6$ & $95 \cdot 8$ & $23 \cdot 9$ & $55 \cdot 5-155 \cdot 3$ \\
\hline C3 & $196 \cdot 3$ & $41 \cdot 2$ & $90 \cdot 6-275 \cdot 5$ & $146 \cdot 6$ & $30 \cdot 3$ & $78 \cdot 3-182 \cdot 0$ \\
\hline $\mathrm{C} 4$ & $37 \cdot 3$ & $12 \cdot 9$ & $19 \cdot 5-64 \cdot 5$ & $33 \cdot 7$ & $11 \cdot 3$ & $17 \cdot 8-60 \cdot 0$ \\
\hline $\mathrm{C} 5$ & $12 \cdot 8$ & $5 \cdot 1$ & $6 \cdot 6-24 \cdot 5$ & $10 \cdot 9$ & $5 \cdot 6$ & $2 \cdot 5-26 \cdot 7$ \\
\hline
\end{tabular}

SI conversion: $\mathrm{mg} / \mathrm{dl} \times 10=\mathrm{mg} / \mathrm{l}$.

Table 2 Serum complement component levels in $\mathrm{mg} / \mathrm{dl}(\mathrm{C3}, \mathrm{C4}, \mathrm{C5})$ and units/dl $(\mathrm{Clq})$ in mild, moderate, and severe types of acute adenovirus conjunctivitis

\begin{tabular}{|c|c|c|c|c|c|c|c|c|c|}
\hline \multirow[t]{2}{*}{ Types } & \multirow{2}{*}{$\begin{array}{l}\text { No. of } \\
\text { patients }\end{array}$} & \multicolumn{2}{|l|}{$C I q$} & \multicolumn{2}{|l|}{$C 3$} & \multicolumn{2}{|l|}{$C 4$} & \multicolumn{2}{|l|}{$C 5$} \\
\hline & & Mean & $S D$ & Mean & $S D$ & Mean & $S D$ & Mean & $S D$ \\
\hline Mild & 5 & $114 \cdot 3$ & $23 \cdot 5$ & $160 \cdot 5$ & $22 \cdot 2$ & $37 \cdot 4$ & $11 \cdot 2$ & $12 \cdot 5$ & $5 \cdot 1$ \\
\hline Moderate & 19 & $94 \cdot 6$ & $20 \cdot 7$ & $150 \cdot 3$ & $25 \cdot 7$ & 33.4 & $12 \cdot 1$ & $10 \cdot 9$ & 5.9 \\
\hline Severe & 5 & $82 \cdot 1$ & $29 \cdot 0$ & $118 \cdot 8$ & $41 \cdot 3$ & $31 \cdot 2$ & $8 \cdot 7$ & $9 \cdot 1$ & $5 \cdot 7$ \\
\hline
\end{tabular}

SI conversion: $\mathrm{mg} / \mathrm{dl} \times 10=\mathrm{mg} / \mathrm{l}$.

conjunctivitis are given in Table 1 . There was no significant change in serum C4 components $(p>0.3)$ and C5 components of complement levels $(p>0 \cdot 2)$, while the serum $\mathrm{C} 3$ component $(\mathrm{p}<0.001)$ and $\mathrm{C} 1 \mathrm{q}$ components of complement levels $(p<0.001)$ fell significantly in comparison with the levels in the healthy subjects.

Table 2 shows the serum $\mathrm{C} 1 \mathrm{q}, \mathrm{C} 3, \mathrm{C} 4$, and $\mathrm{C} 5$ components of complement levels in mild, moderate, and severe types of acute adenovirus conjunctivitis. The serum Clq component of complement level showed a significant fall in moderate $(p<0 \cdot 001)$ and severe $(p<0.001)$ types of disease, while its level in the mild type $(p>0.2)$ remained unaltered in comparison with the levels in the healthy subjects. The serum C3 component of complement level, however, showed a significant fall in all types of the disease $(p<0.005, p<0.001, p<0.001$ in mild, moderate, and severe types respectively). Serum $\mathrm{C} 4$ component of complement $(p>0.99, p>0.3, p>0.2$ in mild, moderate, and severe types respectively) and C5

Table 3 Serum complement component levels in $\mathrm{mg} / \mathrm{dl}$ $(\mathrm{C3}, \mathrm{C4}, \mathrm{C5})$ and units/dl $(\mathrm{Cl} q)$ in acute and remission stages of acute adenovirus conjunctivitis

\begin{tabular}{|c|c|c|c|c|c|}
\hline \multirow[t]{2}{*}{ Complements } & \multicolumn{2}{|c|}{ Acute stage } & \multicolumn{2}{|c|}{ Remission stage } & \multirow[t]{2}{*}{ p value } \\
\hline & Mean & $S D$ & Mean & $S D$ & \\
\hline $\mathrm{C} 1 \mathrm{q}$ & $97 \cdot 3$ & $16 \cdot 2$ & $127 \cdot 6$ & $17 \cdot 6$ & $<0.001$ \\
\hline $\mathrm{C} 3$ & 143.6 & $23 \cdot 3$ & $181 \cdot 7$ & $27 \cdot 1$ & $<0.001$ \\
\hline C4 & $36 \cdot 6$ & $12 \cdot 4$ & $38 \cdot 2$ & $10 \cdot 8$ & $>0.8$ \\
\hline C5 & $11 \cdot 1$ & $4 \cdot 5$ & $12 \cdot 2$ & 3.9 & $>0.6$ \\
\hline
\end{tabular}

component of complement levels $(p>0.95, p>0.3$, $\mathrm{p}>0.2$ in mild, moderate, and severe types respectively) did not show any change in the severity of disease when compared with the levels in healthy subjects.

Table 3 shows the serum complement levels in patients with acute adenovirus conjunctivitis during the acute and remission stages. There was a significant rise in serum $\mathrm{Cla}$ components of complement level $(p<0.001)$ and $C 3$ components of complement level $(p<0.001)$ in the stage of remission. The levels of the 2 complements $\mathrm{C} 1 \mathrm{q}$ and $\mathrm{C} 3$ almost reached the normal values. However, no alteration was seen in the serum C4 $(p>0 \cdot 8)$ and C5 component of complement levels $(\mathrm{p}>0 \cdot 6)$.

\section{Discussion}

Viral diseases associated with serum complement depression have been recognised in man during hepatitis type B, Epstein-Barr infection, dengue haemorrhagic fever, and subacute sclerosing panencephalitis. ${ }^{9} \quad$ Viral-antigen-antibody complex activates the complement system, resulting in inflammatory injury. ${ }^{10-12}$ It has been shown in ocular inflammation that activation of complements either by the classic or alternate pathway may be involved. ${ }^{1314} \mathrm{C} 1 \mathrm{q}, \mathrm{C} 3$, and $\mathrm{C} 4$ components represent acute phase reactant in human serum. ${ }^{15}$ These $3 \mathrm{com}$ plement components in serum were normal or raised during the acute phase and normal in the convalescent phase in patients with Epstein-Barr infection. ${ }^{16}$

C3 component acts as a focal point for activation of 
the terminal complement component leading to membrane damage and lysis. ${ }^{1718}$ A significant depression of $\mathrm{C} 3$ component in serum has been observed in the present study in patients with acute adenovirus conjunctivitis. The role of complement in conjunctivitis has not so far been studied. However, depression of $\mathrm{C} 3$ component in serum has been reported in patients with acute viral lower respiratory tract illness ${ }^{19}$ and Argentine haemorrhagic fever ${ }^{20}$ The $\mathrm{C} 3$ deficiency is of particular importance because it participates in a variety of biological phenomena and is also situated at the pivotal point between the classical or alternate pathway. ${ }^{21}$

Viral lysis initiation is reported to be carried out by C1q component of complement. ${ }^{22}$ A significant depression of serum $\mathrm{Clq}$ component level in patients with adenovirus conjunctivitis has been observed in the present study. C1q component level in serum was reported to be low in Junin virus haemorrhagic fever. ${ }^{20} \mathrm{Clq}$ component is reported to be depressed or absent in severe combined immunodeficiency. ${ }^{23}$ An increased catabolism of $\mathrm{Clq}$ component is probably secondary to low levels of IgG in patients with immunodeficiency. ${ }^{24}$ The present report is in agreement with these findings, for low serum IgG levels have been reported in acute adenovirus conjunctivitis in our earlier report. ${ }^{6}$

Low $\mathrm{C} 1 \mathrm{q}$ and $\mathrm{C} 3$ component levels in serum may be due to the activation of the classical/alternate pathway, transient depression of complement component synthesis, increased catabolism, or the presence of inhibitors of complement action: The reversal of complement components ( $\mathrm{C} 1 \mathrm{q}$ and $\mathrm{C} 3$ ) in serum in the remission stage, as is evident from Table 3 , is interesting, and it is obvious that serum complement component levels tend to attain the normal level as the disease recedes.

\section{References}

1 Ruddy S, Gigli I, Austen KF. Complement system of man. $N$ Engl J Med 1972; 287: 489-92.

2 Galin MA, Goldstein IM. Tuberville AT, Perez HD, Kaplan H. Intraocular lenses generate chemotactic activity in human serum. Arch Ophthalmol 1981; 99: 1434-5.

3 Hirsch RL, Griffin DE, Winkelstein JA. The effect of complement depletion on the course of Sindbis virus infection in mice. $J$ Immunol 1978; 121: 1276-8.

4 Roitt M. Essentials of immunology. Oxford: Blackwell, 1977: 141-7.
5 Mondino BJ, Ratajczak HV, Goldberg DB, Schanzlin DJ, Brown SI. Alternate and classical pathway components in the normal cornea. Arch Ophthalmol 1980; 98: 346-9.

6 Gupta AK, Sarin GS. Serum and tear immunoglobulin levels in acute adenovirus conjunctivitis. Br J Ophthalmol 1983; 67: 195-8.

7 Gupta AK, Prasad AK. Epidemic acute conjunctivitis in Delhi (1981). A virological study. Afro-Asian J Ophthalmol 1982; 1: 62-5.

8 Mancini G, Carbonara AO, Heremans JF. Immunochemical quantitation of antigens by radial immunodiffusion. Int $J$ Immunochem 1965; 2: 235-54.

9 Oldstone MBA. Virus neutralization and virus induced immune complex disease: virus-antibody union resulting in immunoprotection or immunologic injury-two different sides of the same coin. In: Melnick J. Progress in medical virology Basel: Karger, 1975; 19: 84-119.

10 Dayan A, Stokes M. Immune complexes and visceral deposits of measles antigens in subacute sclerosing panencephalitis. $\mathrm{Br} \mathrm{Med}$ $J$ 1972; ii: $374-6$.

11 Henson JB, Gorham JR, Padgett GA, Wash P, Davis WC. Pathogenesis of the glomerular lesions in Aleutian disease of mink. Immunofluorescent studies. Arch Pathol Lab Med 1969; 87: 21-8.

12 Hill RB, Rowlands DT, Rifkind D. Infectious pulmonary diseases in patients receiving immunosuppressive therapy for organ transplantation. N Engl J Med 1964; 271: 1021-7.

13 Mondino BJ, Rabin BS, Kessler E. Corneal rings with Gram negative bacteria. Arch Ophthalmol 1977; 95: 2222-5.

14 Mondino BJ, Brown SI, Rabin BS, Bruno J. Alternate pathway activation of complement in Proteus mirabilis ulceration of cornea. Arch Ophthalmol 1978; 96: 1659-61.

15 Hornung M, Arquembourg RC. $\beta 1 C$ globulin: an acutc phase serum reactant of human serum. J Immunol 1965; 94: 307-16.

16 Boughton CR. Complement, lymphocytotoxins and immune complexes in infectious mononucleosis: serial studies in uncomplicated cases. Clin Exp Immunol 1978; 34: 241-7.

17 Bokisch VA, Dierich MP, Muller-Eberhard HF. Third component of complement (C3): Structural properties in relation to functions. Proc Natl Acad Sci USA 1975; 72: 1989-93.

18 Goldstein IM, Ross D, Kaplan HB, Weissmann G. Complement and immunoglobulins stimulate superoxide production by human leukocytes independently of phagocyosis. J Clin Invest 1975; 56: 1155-63.

19 Strunk RC, Sieber OF, Taussig LM, Gall EP. Serum complement depression during viral lower respiratory tract illness in cystic fibrosis. Arch Dis Child 1977; 52: 687-90.

20 de Bracco MME, Carballal G, Arana RM. Argentine haemorrhagic fever: alteration of the complement system and antiJunin-virus humoral response. N Engl J Med 1978; 229: 216-21.

21 Cochrane CG, Kaffler D. Immune complex disease in experimental animals and man. Adv Immunol 1973; 16: 185-264.

22 Agnello V: Complement deficiency states. Medicine 1978; 57: 1-23.

23 O’Connell EJ, Enriquez P, Linman JW, Gleich GJ, McDuffic PC. Absence of activity of first component of complement in man: association with thymic alymphoplasia and defective inflammatory response. J Lab Clin Med 1967; 70: 715-9.

24 Kohler PF, Muller-Eberhard HJ. Metabolism of human C1q. Studies in hypogammaglobulinemia-myeloma and systemic lupus erythematosus. J Clin Invest 1972; 51: 868-70. 